\title{
Understanding primary stakeholders' multiple roles in hallmark event tourism management
}

\section{Louise Todd, Anna Leask, John Ensor}

\section{Abstract}

This paper contributes insights into stakeholder theory in hallmark event tourism and the implications for engaging primary stakeholders in further tourism management settings. The tangible and symbolic tourism benefits instilled in destinations by hallmark events are welldocumented; with destination managers increasingly adopting event portfolio approaches to nurture and develop existing and new hallmark events. Nevertheless, limited understanding exists of how stakeholders engage with hallmark events over time; their lived experiences in event tourism; and consequent management implications. This paper uncovers multiple and shifting roles of primary stakeholders in a long-established hallmark event tourism context (Edinburgh's Festival Fringe). It presents a typology identifying five primary stakeholder roles. Phenomenological interviews with twenty-one primary stakeholders revealed that most fulfilled multiple roles. Existing concurrently and historically, these differed throughout stakeholders' lived experiences and engagement. In its findings, this paper extends knowledge of stakeholders' roles in event tourism and implications in further tourism management settings.

\section{Key words}

Stakeholders, multiple roles, hallmark event tourism, lived experience

\section{Highlights}

- Primary stakeholders in hallmark event tourism assume multiple roles over time

- Phenomenological interviews reveal lived experiences of salient and multiple roles

- Destination managers must understand primary stakeholders' roles in event tourism

- This paper contributes to stakeholder theory in event tourism management

- Findings are significant to further destination and tourism management contexts

\section{Introduction}

Event tourism has been adopted as a strategic approach throughout the destination management industry and is recognised as a key tourism product (Benur \& Bramwell, 2015; McKercher, 2016). Conceptually, event tourism is gaining interest in the tourism and event research community (Connell, Page \& Meyer, 2015; Kim, Jun, Walker \& Drane, 2015; Patterson \& Getz, 2013; Stokes, 2008). From a management perspective, event tourism is concerned with the production and marketing of events as motivators for tourism; and the 
value of these events within destination management settings. Destination managers, along with event planners and producers, must be in a position to evaluate the tangible economic and marketing impacts of events; while attempting to gain an understanding of events' symbolic influences upon their hosts' destination image and brand (Getz, 2008; Getz \& Page, 2016). Increasingly, such managers are therefore adopting approaches to drive event tourism, thus creating unique selling points and differentiating their destinations from competitors (Getz, Svensson, Peterssen \& Gunnervall, 2012).

Hallmark events are recognised as being valuable to destinations' managed event portfolios as they can make significant tangible and symbolic contributors to event tourism. They can enable opportunities for their host destination to gain competitive advantage in tourism markets while minimising negative impacts upon the local community (Hall, 1989; 1992; Ritchie \& Beliveau, 1974). An early definition of hallmark events was developed by Ritchie (1984) and this highlights their characteristics and impacts:

"Major one-time or recurring events of limited duration, developed primarily to enhance the awareness, appeal and profitability of a tourism destination in the short and/or long term. Such events rely for their success on uniqueness, status, or timely significance to create interest and attract attention." ( $p$ 2).

The literature has considered hallmark events in terms of their definition, function, and form (Getz et al., 2012). They are recognised by their purposeful development and management within tourism destinations, and their status is defined by: longevity; quality of brand image; significance; and value. Although categorisations vary, they are commonly classified as having distinct features. Unlike mega or major events hallmark events are rarely recognised by scale of audience and media interest (Ibid). Nevertheless, they are significant to the appeal and profitability of tourism destinations; and may be nurtured as responses to seasonality (Ritchie \& Beliveau, 1974). Another dimension of hallmark events is their impact upon the international recognition of their host destination; causing them to become tangibly and symbolically embedded as permanent institutions within their community or culture (Ritchie, 1984).

Destination managers can certainly aspire to nurture successful hallmark events and related tourism activity through strategic event portfolio approaches (Getz \& Page, 2016); yet, the particular nature of hallmark events suggests they cannot be created and managed purely through planning efforts. Being unlike other destination-based events, more often defined by scale or form, arguably the less tangible, and occasionally conflicting attributes of hallmark events contribute to them requiring a non-standardised management model. This is an important management consideration and has bearing upon the significance of stakeholders in hallmark event settings (Getz, et al., 2012). Thus, in achieving and attaining hallmark 
status, it is essential to recognise that existing, or would-be, hallmark events must ensure sustained support and resources from numerous stakeholders.

The stakeholder approach suggests that effective management is based upon understanding the often complex relationships with, and amongst, stakeholders. These groups and individuals affect and are affected by organisations, which are in turn dependent upon their key stakeholders (Freeman, 1984). In applying stakeholder theory to event tourism contexts, it is recognised that events can only occur as a result of the interaction of key stakeholders with the managing organisations (Clarkson, 1995). The survival and continued success of hallmark events is therefore dependent on those groups of 'primary' stakeholders who are most involved and engaged (Reid, 2006). Of significance to categorising hallmark event stakeholders is the argument that primary event stakeholders assume multiple roles and these may not be permanent or fixed (Getz et al., 2006; Reid, 2006). Despite the acknowledgment of these shifting roles, there is little understanding of how and at what stages stakeholders assume manifold roles in event tourism settings. Appreciating how and when these engagements occur is relevant to building upon existing stakeholder theory and is pertinent to the tourism management and studies literature.

The purpose of this paper is to provide new insights into primary stakeholders' roles and lived experiences in a hallmark event tourism setting, thus contributing to stakeholder theory and management approaches in event tourism. It reflects upon the implications of these insights to destination managers, event producers and planners. The paper draws from an existing iconic hallmark event setting: the Edinburgh Festival Fringe, which drives event tourism in the capital city of Scotland. Underpinned by stakeholder theory, it presents a hallmark event stakeholder typology, based on Clarkson's (1995) concept of primary stakeholders, who as noted are essential to the continued success of an organisation (Ibid) and were therefore of key concern to this study. The paper firstly adapts a generic stakeholder typology from the literature and, through the use of key informant consultation and document analysis, applies this to the present context. It then presents findings of interviews with twenty-one primary stakeholder informants explored from a phenomenological perspective. Findings reveal new understandings of the various roles assumed by these stakeholders throughout their lived experiences of this particular hallmark event. In uncovering this new knowledge about primary stakeholders' roles in an existing hallmark event tourism context, this paper aims to equip managers with valuable insights into successful stakeholder management in the context of hallmark events. 
The findings of this study are anticipated to be of relevance to current and future strategic event tourism approaches, such as strategic portfolio development. They offer a better understanding of how the changing roles of primary stakeholders can impact upon relationships with long-established hallmark events, leading to sustained success. This has implications for the present and future management of event tourism and stakeholder approaches in destinations and other settings. The paper concludes by considering the management implications of this more in-depth understanding of primary stakeholders' changing roles and lived experiences in engaging with hallmark events; and in their future growth and development. Additionally, it reflects upon the potential benefits of this extension to stakeholder theory in driving event tourism development in destinations; as well as the potential consequences of this in further tourism management settings.

\section{Literature review}

\subsection{Hallmark events}

The frequency and permanence of hallmark events has been debated in the literature with suggestion that they can be one-time occurrences that mark historical occasions (Graham, et al., 1995). Nevertheless, it is commonly argued that to develop hallmark status events must be periodic, and of a limited duration, to gain stature and build reputation over time (Frost, 2012; Getz, 1991). In terms of existing hallmark events, the literature includes examples, such as Ritchie and Belveau's (1974) early study of the Quebec Winter Carnival, existing as an annual seasonal festival since 1894, but officially founded as an event in 1954 to drive tourism and the city's economy. Getz (1993) has studied the Calgary Exhibition and Stampede as an example of a hallmark event. Meanwhile, Ritchie and Crouch (2003, p. 119120) list a series of permanently recurring and periodic hallmark events, including: the Boston Marathon; Munich Oktoberfest; New Orleans Mardi Gras; Running of the Bulls in Pamplona; and Wimbledon Tennis tournament. Frost (2012) names the Indianapolis 500 car race, and suggests that hallmark events may take the form of traditional or modern 'pop' cultural events. In terms of destination management approaches, Getz et al., (2012) discuss the literature and also note the event tourism industry's adoption of the hallmark terminology in practice. They cite examples from Melbourne in Australia and Hamilton in New Zealand where the term 'hallmark' is used in marketing materials to describe cultural, sporting and converged events of a recurring and permanent nature, thus supporting the discussions in the literature.

It is agreed that the functional attributes of hallmark events drive their significance as tourism products within their host destinations, allowing them to be major tangible contributors to event tourism. A key feature of hallmark events is their close association with their host 
destination. They are often co-branded, as illustrated by the examples above; and while of a scale which is significant in attracting visitors and to economic contribution; they must remain relative to their spatial community setting (Hall, 1998). As such, hallmark events are sustainable and beneficial to the community within which they are situated (Getz, 2008). Reflecting upon these tangible features, Hall (1992, p.1) describes hallmark events as the "image builders of modern tourism". Their permanence is thus embedded within destinations to the extent of them becoming symbolic elements of a destination's image and brand (Getz, 2008). Getz (1991) further emphasises the permanence and stature of such events by noting dictionary definitions of 'hallmark' which refer to a differentiating symbolic quality or authenticity. Considering those qualities somewhat less measurable than their permanence, frequency and stature; hallmark events are therefore recognised as having highly visible and positive brands that inspire confidence on a symbolic basis (Getz et al., 2012).

Further highlighting the symbolic attributes of hallmark events, Getz et al, (2012) draw from consumer branding theory to argue that such events may become 'cultural icons' (Holt, 2004). As is the case with established consumer branded products, people and places, some events can thus become iconic in terms of their ability to positively engage and inspire consumers (Getz, et al., 2012; Levy, 2007). In discussing this further, Getz et al., (2012, p. 50) emphasise the important point that, similarly to other such iconic phenomena, hallmark events may not be simply be created; nevertheless, an event "can aspire to be the hallmark of its organizers, venue or location". This is a significant argument and is the case for both those hallmark events that are organically formed over an extended period of time with little management direction; and for those events that have been purposefully designed and developed by destination managers, event planners and producers, with the aspiration of ultimately becoming hallmark in status (Hall, 1989; Getz \& Page, 2016). Both forms of hallmark event have the ability to become iconic in stature and in doing so gain "'mythical standing' through longevity, media attention and positive reputation" (Getz, et al., 2012, p. 51). Hallmark events thus contribute positively to destination image and brand (Getz, 1991) and as such are core products in a destination's managed event tourism portfolio. Therefore, existing institutionalised hallmark events should be actively nurtured by destination managers, while newly created events can be developed by event planners and producers with the aim of becoming hallmark as they become ingrained in the managed tourism context of their host destination.

Based on the previous discussion, it is clear that mature events can become institutionalised as they recur over time. In doing this they become place dependent and embedded within the setting of their host destination thus gaining hallmark status (Getz, 2008). As noted, many hallmark events have developed in an organic fashion, growing from early roots of 
marking socio-cultural celebrations and ideologies in societies and communities (Getz, 1991). With the aim of emulating the success of these events, in more recent times others have been purposefully designed by managers with the aspiration of becoming hallmark (Getz et al., 2012). This is evidenced by destination managers adopting a strategic event portfolio approach where they conceptualise, design, and build destination-based and cobranded events with the aim of these gaining hallmark status in the future (Getz \& Page, 2016). These are often in forms of expositions, sporting events or cultural festivals and developed with the core purpose of driving event tourism (Getz, 2008; Larson, 2009), meanwhile generating positive images in their association with the destination brand (Hall, 1989). These events are thus deliberately developed with the intent of achieving future hallmark status (Getz, 2012) and ultimately of inhabiting a permanent niche in their host destinations and communities, thus gaining legitimacy and value over the course of time (Getz, et al., 2007).

\subsection{Stakeholder theory}

The term 'stakeholder' was first introduced by the Stanford Research Institute in 1963. Stakeholder theory recognises that within any organisational context, there are various individuals and groups who support and influence the organisation, and are reciprocally supported and influenced by it (Freeman, 1984). Stakeholders are therefore "any group or individual who can affect or is affected by the achievement of the firm's objectives" (Ibid, p.25). As a strategic management paradigm, stakeholder theory has been of concern in the literature since the late $20^{\text {th }}$ Century; initially growing from the need to classify and evaluate the concepts of corporate social performance and responsibility (Carroll, 1991). Its core argument is that understanding the relationships amongst groups and individuals affecting, or affected by, the organisation is a useful means of analysis in relation to organisational effectiveness and success (Freeman, 1984). The stakeholder concept has subsequently been debated throughout the management literature in regard to strategic functions such as corporate planning, performance, systems theory and corporate social responsibility (e.g. Ackoff, 1981; Clarkson, 1995; Freeman \& Reed, 1983; Harrison \& Freeman, 1999; Mitchell, Agle \& Wood, 1997; Suchman, 1995). In management practice, stakeholder theory is concerned with ensuring satisfaction and moral responsibility is delivered to a range of groups and individuals, within the context of the organisation. Crucially, these groups and individuals have concerns that exist beyond those of purely financial shareholders (Gibson, 2000). Stakeholder theory therefore requires managers to consider the full range of stakeholders in their unique operational setting; and to ensure the involvement of these actors to build ethical, equitable and successful relationships between an organisation, and individuals, and networks of stakeholders (Campbell, 1997; Donaldson \& Preston, 1995; 
Jawahar \& McLaughlin, 2001; Savage, Nix, Whitehead \& Blair, 1991; Rowley, 1997; Strong, Ringer \& Taylor, 2001).

\subsection{Stakeholder roles}

An organisation may be defined as a system of stakeholders whose aims and objectives must be satisfied (Clarkson, 1995). Indeed, organisational identity is based upon the various prevailing stakeholder relationships (Scott \& Lane, 2000). The management literature proposes the necessity of satisfying the needs of all stakeholders. In order to do this, there is consequently a need for managers to understand the roles of idiosyncratic groups and individuals. (McVea \& Freeman, 2005). In proposing a stakeholder view of an organisation and mapping stakeholders' various roles, the dominant production and management perspectives of organisational structure, were redrawn by Freeman (1984). The resulting framework categorised generic organisational stakeholders, and in doing so illustrated their roles. Stakeholders were thus classified functionally as: owners; consumer advocates; customers; competitors; media; employees; special interest groups; environmentalists; suppliers; governments; and local community organisations. Freeman's (1984) early conceptual framework for mapping stakeholders by their roles, has predominated in the literature (Clarkson, 1995; Frooman, 1999; Fassin, 2009). Nevertheless, it is important to recognise that any organisation's stakeholder context is unique to its bespoke setting on both conceptual and management bases (Donaldson \& Preston, 1995).

Stakeholders' roles within organisations may be identified according to the functions they address; the specific organisational needs they satisfy; and their various operational markets (Strong, et al., 2001). Roles may also be defined in terms of their importance to an organisation over the course of time. Additionally, they can be classified in terms of whether stakeholders' legal, moral and collective rights and interests are related to the past, present, or future (Jawahar \& McLaughlin, 2001). A further means of defining stakeholders' roles is by their comparative salience, which is concerned with the relative prominence of stakeholder groups in terms of their possession of three traits: power, legitimacy and urgency (Mitchell et al., 1997). Power affords influence within an organisation and this is dependent on stakeholders' respective physical and symbolic resources and authority (Larson, 2002; Reid, 2011; Suchman, 1995). Legitimacy is concerned with stakeholders' relationship with the organisation, for example whether they have contractual, legal or ownership rights (Mitchell et al., 1997). Urgency of stakeholders refers to their ability to gain management attention, and their level of demand within the organisation (Heenan, 1978; Reid, 2011). Stakeholders' salience is thus based on their relative authority, as power gains 
this through the legitimacy, and in turn this gains managerial attention through urgency (Mitchell et al., 1997; Magness, 2008).

Related to saliency, and stakeholders' various relationships, both with the organisation and other stakeholders, is the nature of their engagement with the organisation. In this context engagement is described in relation to levels of satisfaction and participation. A useful means of classifying stakeholders' is in terms of whether their relationship with the organisation is primary or secondary (Clarkson, 1995). As mentioned previously, the engagement of primary stakeholder groups is considered as essential to the continued success of an organisation. Meanwhile, although secondary stakeholders are also important to the organisation, being key components of its context, their participation does not have a direct impact on the survival of the organisation. All stakeholders, whether primary or secondary, may be categorised with roles that are variously functional, symbolic and political in nature. Furthermore, stakeholders' relationships with an organisation influence whether they are essential actors within the overall governance of the organisation (Donaldson \& Preston, 1995; Jawahar \& McLaughlin, 2001).

\subsection{Stakeholder theory in tourism and event settings}

The tourism industry involves large numbers of diverse stakeholders who operate both individually and collectively in networks (Jamal \& Getz, 1995; Sheehan \& Ritchie, 2005). The engagement and interactions of relevant tourism stakeholders must therefore be understood by managers in addressing objectives and maintaining success (Andereck \& Vogt, 2000; Beritelli \& Laesser, 2011; Randle \& Hoye, 2016; Sautter \& Leissen, 1999; Timothy, 1999). While stakeholder theory is widely applied in business and organisational management, it remains less explored in the complex and fragmented context of tourism (Garrod, Fyall, Leask \& Reid, 2011; Palmer \& Bejou, 1995). Nevertheless, there is research where stakeholder theory is applied to map key tourism stakeholder groups and understand interorganisational tourism planning (Caffyn \& Jobbins, 2003; Getz \& Jamal, 1994; Robson \& Robson, 1996; Wray, 2011; Yasarata, Altinay, Burns \& Okumus, 2009). Stakeholders have also been studied in destination marketing contexts (e.g. Bornhorst, Ritchie \& Sheehan, 2010; Garcia, Gomez \& Molina, 2012) and, specifically, in terms of branding (Gilmore, 2002; Hankinson, 2004; Pike, 2009). Stakeholder salience (Mitchell, et al., 1997) has been investigated in tourism settings such as destination management (Beritelli \& Laesser, 2011), local residents' engagement with visitor attractions (Garrod et al., 2012). Stakeholder collaboration and relationships have also received conceptual consideration in tourism studies (Jamal \& Getz, 1995; Sautter \& Leisen, 1999); empirically in specific tourism management contexts such as heritage and visitor attractions (Aas, Ladkin \& Fletcher, 2005; 
Garrod et al., 2012); and National Parks (Imran et al., 2014; Randle \& Hoye, 2016; Waligo, Clarke \& Hawkins, 2013).

Despite these existing studies, there remains limited understanding of stakeholders' roles and experiences in specific event tourism settings or how their effective management can impact upon future development (Getz \& Page, 2016). Further, there is little knowledge of stakeholders' roles in the setting of either generic, or named, hallmark events. As discussed, the ability to understand stakeholders' roles and relationships can equip destination managers, event producers, and planners, with tools to enable more effective management of event tourism. These may be used to differentiate destinations and drive tourism through developing and managing existing or new hallmark events in a strategic portfolio approach (Page \& Connell, 2009; Getz, 2008; Getz \& Page, 2016; Hall, 1998). In this context adopting a stakeholder approach can assist managers in a number of ways. Benefits can include identifying existing and potential event tourism and community stakeholders and responding to stakeholders' expectation to meet their needs. In gaining a better understanding of their involvement with event tourism, stakeholders' roles and individual stakes within events may reveal their consumption patterns over time and how this has impacted upon their engagement (Reid, 2011). Similarly to other tourism settings, event tourism contexts are complex, involving numerous actors with a diverse range of stakeholders concerned with achieving sometimes conflicting tourism and event aims (Getz, 2008). Such individuals and groups must be understood, engaged and satisfied throughout the planning process (Reid, 2011). It is essential that managers involved in event tourism therefore recognise the existing relationships amongst stakeholder groups as they interact with events in the destination (Getz, 2002; Andersson \& Getz, 2008; Getz \& Page, 2016).

In keeping with the management literature, event stakeholders are defined as "those people and groups with a stake in the event and its outcomes, including all that participating in the event production, sponsors and grant-givers, community representatives, and everyone impacted by the event" (Getz, 1991, p.15). The event management literature has applied organisational stakeholder theory to both generic and specific event and festival settings as a means of classifying and understanding the roles of stakeholders in particular contexts and event settings. Generic event stakeholder typologies differentiate and classify groups of stakeholders and in doing so illustrate the reciprocal relationships that can exist between events and stakeholders (e.g. Getz, et al., 2006; Hede, 2007; Reid, 2006). These frameworks commonly position the event and its managing organisation centrally and stakeholder groups are typically classified as being in categories of participants and 
spectators, co-workers, the host organisation and community, sponsors and media organisations.

As well as generic stakeholder typologies, the literature defines categories of stakeholders in specific festival and event contexts. For example, the identification and management prioritisation of stakeholders is considered in large scale sporting events (Parent \& Deephouse, 2007; Xue \& Mason, 2011). In the setting of the management of a cultural festival, stakeholders are categorised in functional roles of marketing, production and administration (Spiropoulos, Gargalianos \& Sotiriadou, 2006). Marketing stakeholders and their particular roles are considered in sporting events (Merrilees, Getz \& O'Brien, 2005) and in ownership of festival brands (Mossberg \& Getz, 2006). Event stakeholders have also been studied in terms of their interests, conflicts and power using a Political Market Square (PSQ) network analogy. Here, the access, interactions, and degree of change dynamics characterise PSQs that can identify stakeholders and management approaches which take place in tumultuous 'jungles', dynamic 'parks' or stable 'gardens' as event network metaphors (Larson, 2002; 2009; Larson \& Wikstrom, 2001). As discussed, stakeholders may be understood with primary or secondary roles based upon their saliency and reciprocal relationships with an organisation (Clarkson, 1995). Applying this construct to events, Reid (2006) argues that primary stakeholder groups are essential to the occurrence of events, their continued management success and survival. In the setting of events on a generic basis, primary stakeholders are thus defined as: employees, volunteers, sponsors, suppliers, spectators, attendees and participants, whereas secondary event stakeholders are: government, host community, emergency services, general business, media and tourism organisations (see also Reid \& Arcodia, 2002; Reid, 2011).

The research suggests the original purpose of established hallmark events was celebratory and grounded in particular societies or traditions (Getz et al., 2010). Today's cultural festivals, developed in a largely organic way over time to become hallmark events, may therefore retain non-profit management structures (Mossberg \& Getz, 2006). Newer events, designed by destination management organisations with the aim of becoming hallmark over time; thus contributing to economic impact through event tourism may have a profit-driven management model. In both cases, these events are dependent upon stakeholders with community, consumer, civic, public and private roles (Getz et al., 2010). In the event tourism market place, the ability to understand the nature of stakeholders, including their roles, and lived experiences with existing successful hallmark events as event tourism products, provides managers with valuable opportunities to differentiate their destinations and drive event tourism (Andereck \& Vogt, 2000; Getz et al., 2006; Getz, 2008; Sautter \& Leissen, 
1999; Xue \& Mason, 2011). Therefore, adopting a stakeholder approach can assist managers to: identify existing and potential event tourism and community stakeholders; better understand their relationships, consumption patterns, roles and stakes within events; and respond to the needs and expectations of stakeholders (Reid, 2011). Notwithstanding and also of relevance, is that the complexity of the numerous individuals and groups involved in events and festivals could contribute to the difficulty of mapping all stakeholders in event tourism settings (Larson, 2002; Getz, 2008; Reid, 2011).

The stakeholder approach is significant to achieving management success in hallmark event tourism. In doing this it is essential that managers can understand stakeholders and the nature of their non-permanent and changing primary roles as they change over time (Getz et al, 2007; Reid, 2006). There is a lack of knowledge of the roles played by primary stakeholders in engaging with hallmark events, and the research has not yet defined the various positions assumed by these stakeholders in event tourism contexts. This paper aims to gain an understanding of how and when these primary stakeholder engagements occur. This is significant as it builds upon stakeholder management theory; and it contributes new knowledge of stakeholders to the tourism management and studies literature.

\section{Research setting}

As the setting of this study, the Edinburgh Festival Fringe (The Fringe), is considered the world's largest multi-arts festival. Occurring every August it lasts for three weeks (Edinburgh Festival Fringe, 2016) and is hallmark in status, in accordance with the literature. It demonstrates longevity; an established market; and is a mature and recognised brand which has become synonymous with its host city and embedded in the community (Getz et al., 2012; Hall, 1992; Ritchie \& Beliveau, 1974). The Fringe gained hallmark status over time; and is not the result of directed efforts to build Edinburgh's event portfolio. It was not conceived by destination managers, or event planners and producers. Rather, it first occurred in 1947, when eight theatre groups, not invited to the city's new post-war, International Festival, decided to perform independently (Moffat, 1978). Today's Fringe is supported by numerous civic and private organisations, and the central administrative Festival Fringe Society. The Society was established in 1958, and has responsibility for central ticketing and audience services, publishing the annual Fringe programme, marketing, and liaising with artists and venues (Edinburgh Festival Fringe, 2016). It is not responsible however for managing or programming the festival - the non-curated aspect of the Fringe remains a constitutional policy. Despite its growth the Fringe has retained its open-access ethos, stating that anyone may register as a performer in its programme provided they can secure a suitable venue (lbid). The Fringe is therefore not managed in a traditional sense, 
similarly to many hallmark events, but occurs through the interaction of various stakeholder groups (Reid, 2006).

Edinburgh's event portfolio is comprised from twelve annual festivals and numerous events, which are managed independently. Festival provision in Edinburgh developed from the midTwentieth Century, nevertheless until relatively recently this was developed in an ad-hoc, although collaborative way. Recognising the considered development of event tourism in competitor destinations, a group of government, civic, tourism, arts stakeholders, and the festivals themselves, commissioned industry research to investigate the future of Edinburgh's Festivals. One of the outcomes of this was the establishment of Festivals Edinburgh in 2007. This strategic, umbrella organisation was founded and is managed by the twelve festivals. Today it represents them collectively, and delivers collaborative projects (Festivals Edinburgh, 2016). Being central to Edinburgh's event portfolio, as one of the twelve festivals, the Fringe is significant to Edinburgh's event tourism by volume and economic contribution. To give an indication of its tangible scale and impacts, the 2015 Fringe featured 50,459 performances of 3,314 shows in 313 venues; with an estimated 2,298,090 tickets issued (Edinburgh Festival Fringe, 2015). In its measurable contribution to event tourism, the Fringe generates half of Edinburgh's four-million festival visits annually (Festivals Edinburgh \& BOP Consulting, 2011; BOP Consulting \& Festivals and Events International, 2015). With a clearly defined hallmark status, the Fringe is also a significant symbolic contributor to Edinburgh's experience economy (Pine \& Gilmore, 1999), festival city reputation (BOP Consulting \& Festivals and Events International, 2015; Richards \& Palmer, 2012) and its event tourism portfolio (Getz \& Page, 2016).

Many hallmark traits of the Fringe have developed organically (Ind \& Todd, 2011; Todd, 2014). Even its name is not a management-created brand, but was first assigned by playwright, Robert Kemp, writing in 1948 of the activities "round the fringe of the official Festival" (Moffat, 1978, p. 17). Since then the Fringe has become institutionalised; permanently embedded in its community (Getz, 2008); and is a major contributor to event tourism in Edinburgh. The 'Fringe' brand name has over time therefore become synonymous with Edinburgh: with the festival becoming place dependent and a conduit for the identity of Edinburgh (Gibson \& Davidson, 2005; Quinn, 2005; Van Aalst, \& van Melik, 2012).

Significantly, as an iconic and trusted brand, the name 'Fringe' has extended beyond its association with Edinburgh, recently being adopted by destinations internationally. For example, Adelaide, Brighton, San Francisco, Shenzen, Stockholm and Vancouver are amongst approximately 230 tourism destinations hosting Fringe-branded festivals today 
Todd, L., Leask, A. \& Ensor, J. (2016). Understanding primary stakeholders' multiple roles in hallmark event tourism management. Tourism Management. 59, pp.494-509. DOI: http://dx.doi.org/10.1016/j.tourman.2016.09.010

(World Fringe Network, 2016). The title 'Fringe' has thus become recognised as a marker of alternative, cutting edge arts; and denotes open-access programming elements.

\section{Methodology}

The research approach for the present study was philosophically underpinned by constructivism, where realities are socially constructed, knowledge formation is transactional, and findings are co-created (see discussions in: Crotty, 1998; Delanty, 1997; Denzin \& Lincoln, 2011; Lincoln, Lynham \& Guba, 2011; Pernecky, 2012; Roth \& Breuer, 2003). The methods were qualitative, involving document analysis, key informant consultation and interviews with stakeholder informants. The interview method was informed by a phenomenological perspective. Phenomenology was initially associated with Husserl's studies of consciousness and experience, then consequently developed by Heidegger to include the human life world experience; the body and action by Sartre, and Merleau-Ponty amongst others (Berger \& Luckmann, 1991; Cresswell, 2013; Denzin \& Lincoln, 2011; Kvale, 1996; Kvale \& Brinkmann, 2009; Pernecky \& Jamal, 2010; Thompson, Locander \& Pollio, 1989; Ziakas, \& Boukas, 2014). Drawing from this paradigm, a phenomenological perspective is used in interviews to gain an "understanding [of] social phenomena from the actors' own perspectives and describing the world as experienced by the subjects" (Kvale \& Brinkmann, 2009, p.26). The interview process of the present study was thus concerned with entering primary stakeholder informants' life-worlds without preconceptions and focusing on their accounts of first-hand lived experiences of the Fringe, from a first-person perspective (Fournier 1998; Kvale \& Brinkmann 2009). Phenomenology has so far received limited attention in event tourism studies, despite lived immediate experiences being the core phenomenon of events (Ziakas, \& Boukas, 2014). The present phenomenological approach was therefore applied to understanding the primary stakeholders' lived experiences in engaging with and consuming the Fringe; and their roles and relationships with it as a hallmark event over time (Thompson et al., 1989). Being concerned with conscious experience, rather than subconscious stimuli, a phenomenological interview design was appropriate for the purpose of this study (Ziakas, \& Boukas, 2014).

The method of defining the Fringe primary stakeholders, then exploring their roles in more detail, involved two stages. Firstly, following the literature review, potential Fringe stakeholders were categorised through the use of secondary data and a consultation with Society managers as key informants (Marshall, 1996b). The evaluation of the Fringe stakeholder context was initially undertaken through examining a selection of published documents including annual reports, programmes and marketing communications materials, 
and the Fringe website. This informed the contextual details of the potential stakeholders in this hallmark event setting. The process drew from the primary and secondary categories of Clarkson's (1995) generic and Reid's (2006) conceptual event stakeholder typologies. It adapted these to the Fringe hallmark event tourism setting, thus addressing the gap in existing knowledge. Being at the centre of the present study, primary stakeholders were initially categorised as: Fringe Society staff, volunteers and board members; performing companies; venues; promoters; bookers; audience members; Scottish government agencies; civic bodes; supporting organisations, including: Festivals Edinburgh, the umbrella organisation responsible for the long-term development of Edinburgh's twelve city-wide festivals, Event Scotland, the National Events Agency for Scotland, and sponsors.

Following the development of the initial primary stakeholder categories, these were presented to two Society management staff, acting as key informants (Marshall, 1996b). There followed a consultation, during which the concept of primary stakeholders was discussed, drawing from the literature. The key informants were asked to consider and define categories of primary stakeholders based upon characterising such groups as those that are: essential to the existence of the Fringe; the most engaged groups incurring associated risk; and essentially, their interactions result in it occurring as a hallmark event (Reid \& Arcodia, 2002; Reid, 2006). This process facilitated the production of an agreed contextually situated Fringe stakeholder typology framework detailing broadly defined stakeholder groups and the roles within these. There were five primary stakeholder categories identified: organising, participating, attending, supplying and supporting stakeholders. Please refer to Figure 1 (below), which illustrates the stakeholder typology. This stage of the research was concerned with addressing the theoretical gaps in understanding the roles of primary stakeholders in hallmark event tourism settings by applying existing typologies to the specific Fringe context.

Despite secondary stakeholders' roles not being within the parameters of the present study, it must be emphasised that secondary stakeholders are also significant to hallmark events, and consequently, within event tourism management settings. Secondary categories include the contextually unique stakeholders of the destination, including the host community and tourism organisations: both being essential to event tourism contexts. Notwithstanding, their importance and synergy in event tourism terms, these stakeholders are not essential to the management of the Fringe and its occurrence as a hallmark event (Clarkson, 1995; Reid, 2006). Within event tourism, it is nevertheless essential that the bespoke characteristics of the host community, including demographics and psychographics; alongside its unique physical and geographical setting are understood in the greater event tourism context 
(Delamere, Wankel \& Hinch, 2002; Smith \& Jenner, 1998). The secondary stakeholders included in the typology, as detailed in Figure 1, form a further non-hierarchical network, interwoven with that of the primary stakeholders. Secondary stakeholder relationships with the Fringe are thus represented by their overlap with the primary stakeholders' network. To differentiate the secondary from primary stakeholders, the connecting lines are noncontinuous in Figure 1 as these groups interact with one another and the Society in various direct and indirect ways, but are not of primary significance to the management of the Fringe occurring as a hallmark event

Figure 1: Stakeholder typology of a hallmark event in the context of event tourism: The Edinburgh Festival Fringe

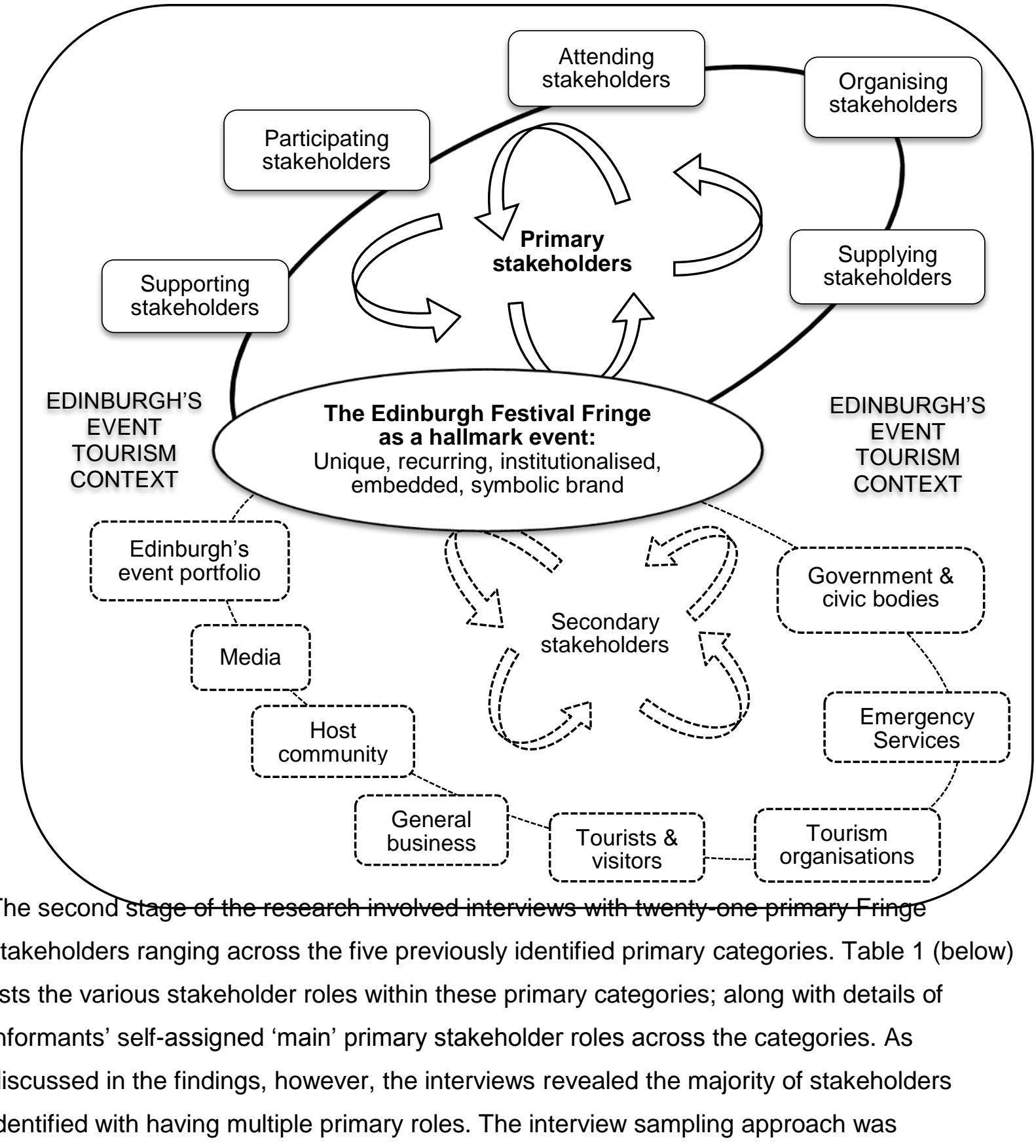


'snowballing' (Goodman, 1961) where the first stakeholder informants were asked to suggest further potential interviewees, based upon their theoretical relevance of fitting within at least one of the primary stakeholder categories (Carson, Gilmore, Perry, \& Gronhaug, 2001; Marshall, 1996a, 1996b).

Interviews took place at various locations in Edinburgh, as selected by informants, including work places, public cafes and libraries. They lasted between forty and ninety minutes, with most around one hour. Interviews continued until theoretical and thematic saturation was evident (Morse, 1992; Marshall, 1996a). As noted, the interview approach was modified from a design and analysis framework inspired by a phenomenological perspective The interview design therefore aligned to key aspects of qualitative research interviews as forwarded by Kvale and Brinkman (2009), This has twelve phenomenological traits, including: being concerned with informants' lived experiences within their life-worlds; the meaning of central themes within these; and obtaining descriptive and nuanced details of specific lived experiences. Also, the researcher adopts a position which is open to new and unexpected phenomena, thus bracketing any presumptions, while the interview design is focused on particular themes, but is neither strictly structured nor undirected (Ibid). Therefore, during the interviews, themes of informants' roles and lived experiences as primary Fringe stakeholders; and related to features of hallmark events were sought. An interview guide was used with loose questions developed in a semi-structured format and this drew from a series of themes around hallmark events and stakeholders' roles. Informants required different probes, and responses were elicited to different levels based on the initial answers given.

Interviews were audio-recorded with informants' consent. In the analysis, in accordance with the phenomenological framework design, initial verbatim transcription of the interviews was completed; and informants' identities were anonymised by assignation of the letters of English alphabet from $A$ to $U$ (see Table 1). The transcripts then became the basis of the phenomenological interpretation (Thompson, et al., 1989). Following this, a cross-case analysis of the transcripts identified common primary stakeholder themes. The idiographic stage involved viewing each transcript as a whole and interpreting each one by relating particular parts of the text to its overall meaning. The cross-case stage involved relating the interview transcripts to one another to identify common global themes until theoretical saturation of the themes was evident. This was achieved by examining the themes developed from the interviews to determine the point at which no new themes were emerging from the data (Kvale \& Brinkman, 2009; Thompson et al., 1989; Ziakas \& Boukas, 2014). In keeping with the constructivist paradigm, and being concerned with informants' perspectives of their lived experiences, rather than ascribing to concerns of validity over the 
quality of the inquiry, this study was conducted with considerations of trustworthiness. This ensured the credibility, transferability and confirmability of the data emerging from the present phenomenological approach as described (Denzin \& Lincoln, 2011; Kvale \& Brinkmann, 2009).

Table 1: Fringe primary stakeholder categories, roles and informants with selfassigned 'main' roles.

\begin{tabular}{|l|l|c|l|}
\hline $\begin{array}{l}\text { Primary } \\
\text { stakeholder } \\
\text { categories }\end{array}$ & $\begin{array}{l}\text { Stakeholder roles within primary } \\
\text { category }\end{array}$ & $\begin{array}{l}\text { Inform } \\
\text {-ants } \\
\mathbf{( = 2 1 )}\end{array}$ & $\begin{array}{l}\text { Informants' anonymised } \\
\text { identities }\end{array}$ \\
\hline Organising & $\begin{array}{l}\text { Festival Fringe Society Board } \\
\text { members, staff \& volunteers }\end{array}$ & 3 & A, B, C \\
\hline Participating & $\begin{array}{l}\text { Performing companies, independent } \\
\text { venues (staff, programmers, } \\
\text { bookers) }\end{array}$ & 7 & D, E, F, G, H, I, J \\
\hline Attending & $\begin{array}{l}\text { Audience, ticket-buying public, other } \\
\text { attendees }\end{array}$ & 4 & K, L, M, N \\
\hline Supplying & Ticketing suppliers, design agency & 2 & O, P \\
\hline Supporting & $\begin{array}{l}\text { Government \& civic organisations, } \\
\text { grant funders, independent sponsors }\end{array}$ & 5 & Q, R, S, T, U \\
\hline
\end{tabular}

\section{Findings and Discussion}

\subsection{Development of a hallmark event stakeholder typology}

As discussed, the hallmark event stakeholder typology (see Figure 1) was developed as a result of the literature review, document analysis and consultation with the key informants. This typology illustrates various relationships existing amongst the Fringe and its primary and secondary stakeholders in Edinburgh's event tourism context. As shown in Figure 1, the Fringe is delivered as a result of interactions amongst the five primary groups of organising, participating, attending, supporting and supplying stakeholders. Their relationships are nonhierarchical, continuous, and dynamic. Primary stakeholders assume interconnected roles, as represented by the solid continuous lines and their positions within the network.

\subsection{Primary stakeholder roles}

Stakeholder theory recognises that destination managers, planners and producers of hallmark events within event tourism settings must integrate primary stakeholders within the strategic management process (Clarkson, 1995; Getz, et al., 2007; Reid 2006). It is also important to consider saliency attributes of power, legitimacy and urgency in understanding primary stakeholders' roles (Jawahar \& McLaughlin, 2001; Mitchell et al., 1997). The five broadly defined primary stakeholder groups and the roles within these may thus be considered in terms of their engagement and saliency within the Fringe hallmark event tourism context. As detailed in Table 1, firstly organising stakeholders include Fringe staff, 
volunteers and Society members, contribute directly to the festival and have high levels of legitimacy within the organisational decision-making process (Freeman, 1984; Reid, 2006, 2011). Fundamentally, an event cannot function without the support and participation of employees (Reid \& Arcodia, 2002) and vitally, its vision and philosophy must be shared by the whole team, from managers to temporary staff (Bowdin et al., 2011). The Society operates with a small core staff across five management functions of: administration; finance; participant services; external affairs; and marketing and sponsorship. Additionally, prior to and during the Fringe, staffing increases significantly as over one hundred temporary, seasonal paid staff and volunteers, are recruited (Edinburgh Festival Fringe, 2016). The Society remains a charitable, limited company which is not responsible for management decisions. A Board of Trustees oversees its work, while it determines the open-access policy and the Trustees' annual election. Today the Society is responsible for ensuring the Fringe continues in this way, however, the Fringe itself is not managed by one or more dominant stakeholders (Edinburgh Festival Fringe, 2016).

The primary categories of participating and attending stakeholders account for the largest volume of Fringe stakeholders, as illustrated by the published annual data mentioned earlier (Edinburgh Festival Fringe, 2016). Individual roles within the participating and attending stakeholder categories have various involvements, but high levels of saliency. The performing companies and independent venues are involved with producing and presenting Fringe events and are legitimate and powerful stakeholders. Indeed, the participation of these groups are the basis of its programme, as they pay an administration fee to the Society be included in this (lbid). These stakeholders have clear economic and social impacts upon the Fringe and within the hallmark event tourism context (Delamere, 2001; Delamere, et al., 2002; Fredline, 2000; Quinn, 2005). This is also evident in terms of the attending stakeholder groups of audience, ticket-buying public and other attendees, whose consumption of the Fringe counter-balances its production. Conversely, forming the smallest primary category but with high levels of power, legitimacy, and urgency are the supplying stakeholders: identified as primary when goods or services are provided directly (Reid, 2006). Two supplying roles were primary: the ticketing suppliers and the design agency contracted to the Fringe. As a small organisation, it does not have the internal staffing structure to support these vital functions and notably, both suppliers also provide additional seasonal staffing.

Of key importance to the Fringe are the primary supporting stakeholders. This category includes funders and non-financial supporters, directly involved in supporting the Fringe as a 
hallmark event, and comprising the grant funding agencies and steering committees within Edinburgh's event tourism context. This category is destination-specific, so in this event tourism context includes: Festivals Edinburgh (the umbrella organisation responsible for Edinburgh's festivals); EventScotland (Scotland's National Events Agency) within VisitScotland (Scotland's National Tourism Organisation); Creative Scotland; Scottish Enterprise; and those departments of the City of Edinburgh Council directly involved in arts development and the city's marketing and event portfolio strategies. Sponsors are also demonstrative of salient traits in their roles, having the ability to increase sponsees' brand awareness, thus contributing to positive brand image (Coughlan \& Mules, 2001; Gwinner, 1997; Reid \& Arcodia, 2002). Indeed, sponsors' role in branding new events can assist in increasing positive brand equity (Mossberg \& Getz, 2006), a key feature of hallmark events (Getz et al., 2007; Ritchie, 1984).

\subsection{Uncovering multiple primary stakeholder roles}

As noted, managers must understand primary stakeholders' impact and engagement, and in doing so be able to differentiate amongst them (Reid, 2006). The essential nature of such stakeholders' relationships with organisations suggests they may have opportunities to assume various roles and attachments that affect organisations in different ways (Clarkson, 1995). Additionally, primary stakeholders' roles are not always mutually exclusive, due to the complex attributes of event tourism contexts (Garrod et al., 2010; Getz, et al., 2007). In the present study based on the literature and sampling method, some evidence of multiple roles amongst the stakeholders was anticipated. However, the interviews revealed extensive blurring and overlap of roles across the five categories. During the interviews, informants were asked to describe their first ('main') stakeholder role and any other roles. Second ('subsequent') stakeholder roles were reported in nineteen of the twenty-one cases with seven informants reporting a third ('additional') primary stakeholder role. Of these multiple roles, it became evident that some existed concurrently while others were historic and had shifted over time. The various roles are detailed below in Table 2. For the purpose of differentiating the multiple primary stakeholder roles, throughout the following discussion, informants' first roles are referred to as 'main'; while second roles are 'subsequent', and third roles are 'additional'. As detailed in Table 2, all twenty-one 'main' primary stakeholder roles existed currently, and were spread across the five categories.

Table 2: The multiple roles of Fringe primary stakeholders

\begin{tabular}{|l|l|l|l|}
\hline $\begin{array}{l}\text { Fringe primary } \\
\text { stakeholder category }\end{array}$ & $\begin{array}{l}\text { 'Main' primary role: } \\
\text { informants } \\
\text { (current/historic) }\end{array}$ & $\begin{array}{l}\text { + 'Subsequent' } \\
\text { primary roles: } \\
\text { informants } \\
\text { (current/historic) }\end{array}$ & $\begin{array}{l}\text { + 'Additional' primary } \\
\text { roles: informants } \\
\text { (current/historic) }\end{array}$ \\
\hline
\end{tabular}




\begin{tabular}{|l|l|l|l|}
\hline Organising & 3 (current) & 3 (historic) & 2 (historic) \\
\hline Participating & 7 (current) & 1 (current) & 3 (historic) \\
\hline Attending & 4 (current) & 15 (current) & 2 (current) \\
\hline Supplying & 2 (current) & 0 & 0 \\
\hline Supporting & 5 (current) & 0 & 0 \\
\hline Total & $\mathbf{2 1}$ & $\mathbf{1 9}$ & $\mathbf{7}$ \\
\hline
\end{tabular}

Regarding the nineteen 'subsequent' primary stakeholder roles, the majority (fifteen) of informants described 'subsequent' +attending stakeholders in addition to their 'main' primary role. These were all current, suggesting a dual current primary stakeholder role for most informants. Thus those, who described themselves 'mainly' as organising, participating, supplying or supporting stakeholders, were also 'subsequently' audience members or other attendees. It is of course unsurprising that all informants currently attended the Fringe, given the categories of these stakeholders' 'main' primary role. This suggests the majority of primary stakeholders are engaged with the Fringe on a basis beyond attending, being professionally involved in some way. There were four further 'subsequent' primary roles reported. One was a currently participating stakeholder (performer). The other three were formerly organising stakeholders (staff, volunteers, Society members) who self-defined as currently 'main' attending stakeholders.

Seven informants reported an 'additional' primary stakeholder role. Two were concurrent and involved third roles as +attending stakeholders. These were 'additional' to the informants' 'main' and 'subsequent' roles as organising and +participating stakeholders in both cases. The five remaining 'additional' stakeholder roles were historic. One was a former organising stakeholder, who was currently also a supporting stakeholder ('main'), and an attending stakeholder ('subsequent'). The final three 'additional' roles were historical participating roles. These were former performers and venue managers with current 'main' and both current and historic 'subsequent' roles spread across the organising, participating and attending stakeholder categories. To illustrate these different types of primary stakeholder engagements and provide insight into informants' various roles, the findings from the interviews are now discussed in detail.

\section{4 'Main' primary stakeholder roles}

Although all twenty-one informants could define their 'main' primary stakeholder role, only two easily did. Both characterised themselves as audience members within the attending stakeholder category. Informant $\mathrm{M}$ was a life-long Edinburgh resident, who identified her role as a loyal Fringe audience member, having attended for more than twenty years: "[l am] very proactive! I'm not a fair weather fan. I'm a dedicated follower". She described the Fringe and its connection to Edinburgh in highly positive terms as "just fantastic" and referred to the 
Todd, L., Leask, A. \& Ensor, J. (2016). Understanding primary stakeholders' multiple roles in hallmark event tourism management. Tourism Management. 59, pp.494-509. DOI: http://dx.doi.org/10.1016/j.tourman.2016.09.010

exciting atmosphere in Edinburgh while the Fringe was taking place: "I love the atmosphere... it's the festival and the buzz really starts in the city". Informant M revealed an enthusiastic relationship with the Fringe and its hallmark characteristics, including the iconic brand (Getz et al, 2012). She keenly awaited the publication of the Society-produced branded Fringe programme every June, to book her preferred performances in advance.

The second informant with one 'main' primary stakeholder role was Informant N, also an audience member of around twenty years. He moved to Edinburgh after experiencing the Fringe. Although this was principally for employment reasons, Informant $\mathrm{N}$ emphasised his lived experiences of the Fringe as an event tourist had influenced his decision to relocate: "It's fantastic. It's one of the reasons we moved here. It wasn't the main one, but it was definitely one". This is interesting in terms of definitions of the tangible and symbolic contributions of hallmark events to event tourism and host destinations (Getz et al., 2012;) as Informant N's lived experiences of event tourism in Edinburgh had clearly influenced his decision to become a resident, thus this particular stakeholder engagement had ensured the Fringe became embedded in his life-world and community (Getz, et al, 2007; 2012; Hall, 1989; Ritchie, 1984;). Informant N described attending the Fringe to experience live music and comedy: "It's once a year, [we] make the most of it! ...even if it's something at eleven o'clock on a Thursday night and we're up at six the next morning." He termed his lived experiences of the festival atmosphere in Edinburgh similarly to Informant M as "the buzz and all the crowds that very much remind me of the Fringe and Edinburgh", demonstrating the synergy between the destination and event (Getz \& Page, 2016).

Interestingly, despite being long-term audience members with positive primary stakeholder engagements with the Fringe as a hallmark event, neither Informants $\mathrm{M}$ nor $\mathrm{N}$ had 'subsequent' or 'additional' roles with the Fringe. It is important to note that being attending stakeholders, the relationships of Informants $\mathrm{M}$ and $\mathrm{N}$ with the Fringe were on voluntary bases. Due to the significant volume of attending stakeholders collectively this group are highly salient in terms of their power, legitimacy and urgency (Mitchell et al., 1997; Parent \& Deephouse, 2007). Nevertheless, Informant M's and N's encounters as attending stakeholders reflected the literature defining hallmark events, as seen in their personal, longterm engagements with the Fringe. Additionally, their recognition of the relationship between the city and the iconic hallmark event brand was evidenced through linkages between the Edinburgh's atmosphere and the enjoyment of the Fringe. Similar observations of festivity and the character of Edinburgh were seen in all discussions around attending stakeholder engagements, whether these were in 'main', 'subsequent' or 'additional' roles. 
Todd, L., Leask, A. \& Ensor, J. (2016). Understanding primary stakeholders' multiple roles in hallmark event tourism management. Tourism Management. 59, pp.494-509. DOI: http://dx.doi.org/10.1016/j.tourman.2016.09.010

\section{5 'Subsequent' primary stakeholder roles}

Nineteen informants described 'subsequent' primary stakeholder roles. Of these, fifteen identified being + attending stakeholders concurrently with their 'main' roles. In all cases these were reported by informants whose 'main' primary assignation with the Fringe fell within professional roles. Their 'subsequent' primary roles as +attending stakeholders revealed engagements based upon enjoyment, excitement and atmosphere when attending the Fringe; its position in Edinburgh's event tourism offer; and its brand, resonating with the hallmark event descriptors seen in the literature (Getz et al., 2012; Hall,1992; Ritchie, 1984). Informants who reported attending stakeholder roles therefore demonstrated similar involvements, whether 'main' or 'subsequent' in nature. There were a number of cases of blurred roles, specifically within 'main' sub-categories of: supporting, participating, supplying and organising +attending primary stakeholders. All of these 'main' stakeholder roles were professionally engaged with the Fringe and possessed high levels of saliency and this was evident from the interviews (Mitchell et al., 1997).

\subsection{1 'Main' supporting + 'subsequent' attending stakeholder roles}

Supporting primary stakeholders with financial interests in events have high levels of saliency in terms of power, legitimacy and urgency (Garrod et al., 2010; Mitchell et al., 1997). This was clear from the interview findings, as were differences between professional supporting and personal attending roles. For example, as one of four supporting +attending stakeholders, Informant T worked in a government arts-funding organisation. She described her 'main' supporting role with the Fringe in professional partnership terms saying: "we are a project team... there's a shared ambition". Conversely, when speaking of her 'subsequent' +attending role, similarly to all attending stakeholders, she discussed Edinburgh's atmosphere, emphasising the individual perspective of her +attending role: "personally I enjoy the exuberance that comes through, that sense of excitement that takes over the city". Informant T's comments about the team of supporting stakeholders working with the Fringe were echoed by those other informants with supporting +attending roles.

Informant $Q$, a sponsor and audience member, described her 'main' supporting role in terms of the time and energy required to develop the opportunities and "benefit(s) from working together" along with remarking on the Fringe brand's synergy with Edinburgh being influential upon her 'main' role: "Edinburgh... as a destination is very closely tied to the brand and the festival is as well". This suggests her recognition of the interaction between hallmark events and host destinations, in line with the literature (Getz et al., 2012). Informant $Q$ discussed her 'subsequent' + attending role in similar terms, highlighting the impact of the 
Fringe on Edinburgh as an event tourism destination as being: "very messy... like there is stuff everywhere, but (there's) that vibrancy and that just wanting to be part of it". Informant $\mathrm{U}$, the third supporting +attending stakeholder worked in a civic department. He also spoke of a supporting relationship with other stakeholders: "we are all part of 'team Edinburgh"'. Informant S, the final supporting +attending stakeholder worked in a civic-based support role, described her first primary stakeholder engagement in terms of being the "older brother" to the Fringe within the "family of stakeholders". Her allusion to partnership themes extended to an interpersonal basis of kinship, demonstrating hallmark event qualities of longevity and personal embedding of the brand (Getz et al., 2012). Both Informants $U$ and $S$ described their Fringe attendance in terms of the city's atmosphere and the symbiotic relationship between the Fringe and Edinburgh. These descriptive terms reflecting the nature of hallmark events, according to the literature, also emerged in further interviews where stakeholders discussed participating, supplying and organising roles.

\subsection{2 'Main' participating + 'subsequent' attending stakeholder roles}

Five informants with 'main' participating stakeholder roles had 'subsequent' roles as +attending stakeholders. Fringe participants have diverse roles including performing companies, and independent venues. Due to the nature of participating roles, these groups have high salience levels, being in a mutual power-dependence relationship and having a contractual relationship on the basis of their inclusion in the programme Fringe (Carroll, 1991; Clarkson, 1995). All five informants revealed similar power dependency-based engagements with the Fringe and legitimate claims (Mitchell et al., 1997). For example, Informant G identified herself as "right now a venue artistic director". She described this role as involving "making friends, joining up and networking". Informant G had been a performer with the Fringe from the 1970s, then a promoter, before moving to her current venue-specific role in the 1990s, so had a longstanding involvement as a participating stakeholder. She described her 'subsequent' + attending role dating back to her childhood fifty years previously, reporting similar positive terms as other attending stakeholders of the atmosphere and excitement brought to Edinburgh by the Fringe:

"An overarching relationship I've got with the Fringe is from when I was about six years old... feeling the difference in the atmosphere of the city and not knowing what it was. Then finding out later, noticing that it happened once a year and that there were more interesting people in the city than normal and there was a buzz about it" (Informant G: participating +attending stakeholder)

Further informants in the participating +attending primary category included Informant $\mathrm{E}$, whose 'main' primary role was a venue manager and 'subsequent' role an audience member. She described attending Fringe events outside of work, saying: "personally I love it, 
and even in my spare time I will still go". Informant l's 'main' stakeholder role was a venue marketing manager and 'subsequent' role an audience member. He had a participating stakeholder role with a number of Edinburgh's festivals, but discussed his personal enjoyment of the Fringe balanced with his professional role, requiring him to "try and separate them out'. He described various involvements with the Fringe and a blurring of stakeholder roles over time, as is expected in event tourism settings (Garrod et al., 2010; Getz, et al., 2007). Another in this group, was Informant D, an amateur actor who had performed in Fringe productions for more than twenty years while attending as an audience member. She described a similarly blurred relationship in line with the literature: "My role is mostly a performer. I used to try and see a lot of shows as well, but it has got increasingly expensive, so I have to be careful what I choose". Informant D spoke of her engagement in both of her primary roles, with themes of enjoyment and excitement as well as networking with other stakeholders:

"We did a great show. You did your performance [and] you were there until three or four o'clock in the morning, then you got up the next morning and went to work. For me that was the best Fringe experience I ever had, because you saw so many different shows and met so many artists" (Informant D: participating +attending stakeholder)

The final member of the participating +attending stakeholders' group was Informant $\mathrm{H}$, who revealed the longest relationship with the Fringe. He had been an actor and director within an amateur theatre company for over forty years. He first performed at the Fringe in 1959 and recalled attending since its earliest years. He described highly positive participating +attending roles, with emerging themes of enjoyment and team-work:

"That period in August is one of... if not 'the', highlight of my year [and] it's the highlight of the theatre company's year as well...It involves a lot of people... wardrobe, costume, lighting, stage and all that. It always involves another half-adozen people each night to do the front-of-house jobs. It's a team-building exercise" (Informant $\mathrm{H}$ : participating +attending stakeholder)

\subsection{3 'Main' supplying + 'subsequent' attending stakeholder roles}

Two informants $(\mathrm{O}$ and $\mathrm{P})$ described current supplying +attending primary stakeholder roles. Both demonstrated high saliency levels in all three measures of mutual power-dependency, legitimacy in their contractual claims with the Fringe, and urgency within it (Mitchell et al., 1997). Informant $P$ established a ticketing company twenty-three years previously and had supplied the Fringe for sixteen years. He described an "extremely close" relationship: "We kind of 'are' the Fringe ... as much as the Society is". This statement illustrates his salience as a stakeholder. Similarly to other stakeholders' engagements grounded in professional 
characteristics, Informant P described an institutionalised and interpersonal relationship with the Fringe in his 'main' supplying role, describing: "a family relationship... it's like a close-knit family, because we occasionally fall out". In terms of his +attending stakeholder role, Informant P spoke of the "amazing people and crowds" characterising the hallmark event atmosphere in the city, but reflected on his lived experiences as being: "positive, because it's how we make our living".

Informant $\mathrm{O}$, the second supplying stakeholder, directed a design agency and there was evidence of high saliency levels in his 'main' stakeholder role. His 'subsequent' +attending role extended over thirty years since childhood when he visited to Edinburgh to attend the Fringe. Informant $O$ described both engagements in similar terms and did not wholly distinguish between his 'main' supplying and 'subsequent 'attending roles. In fact, he viewed his 'main' supplying role as integral to the Fringe, as continuing beyond the workplace: "we have our own sort of Fringe guide of shows that we have seen. We post them up with reviews, so that we could kind of recommend them to each other".

\subsection{4 'Main' organising + 'subsequent' attending stakeholder roles}

The final informant with two primary stakeholder roles was Informant $B$, who described her organising +attending engagement with the Fringe. Both roles were current as she had been involved with the Society for twelve years and during this time attended the Fringe.

Discussing her 'main' role as an organising stakeholder, which through her involvement with the Society was inherent with high levels of power, legitimacy and urgency, Informant B spoke of being "hugely proud" of the Fringe, saying: "It needs proper care and attention and I am giving it that". In her +attending engagement with the Fringe she described it as being "exuberant and entertaining... I think it's just the most wonderful thing ever".

Notably, the interview findings revealed that all 'main' and 'subsequent' attending primary stakeholder roles were positive with themes emerging of the festival atmosphere in Edinburgh and lived experiences of excitement and enjoyment of the Fringe, thus supporting the literature defining hallmark events. This is expected as attending stakeholders are the only group to be engaged entirely voluntarily. Nevertheless, those stakeholders with a 'main' engagement as supporting, participating, supplying or organising; and 'subsequent' +attending stakeholders also revealed positive engagements in these 'main' non-voluntary, professional relationships with the Fringe. As discussed, there was evidence of partnerships, with allusions to interpersonal friendship and family-based relationships with the Fringe across all of the previously discussed cases. The remaining three +attending stakeholders (discussed below) revealed a third 'additional' primary engagement along with four others. 
These included three informants within the 'subsequent' +organising category on a historical basis; and one in the current 'subsequent' role of a +participating stakeholder.

\section{6 'Additional' primary stakeholder roles}

Seven informants described three primary stakeholder roles ('main', 'subsequent' and 'additional'). All were complex and relatively salient, had evidence of blurring, and tended less to occupy commonly shared stakeholder sub-categories. Notably, all stakeholders with three roles were presently (two), or had historically been (five), involved as organising stakeholders, demonstrating legitimacy in the Fringe (Mitchell et al., 1997). Furthermore, all were currently attending stakeholders in their 'main', 'subsequent' or 'additional' roles. This group revealed the most engaged relationships of all. Most described one current 'main role: but emphasised further roles, either presently, or historically. This was particularly evident across 'main' and 'subsequent' roles in attending and participating stakeholder categories.

\subsection{1. 'Main' attending + 'subsequent' organising + 'additional' participating stakeholder roles}

In this group, Informants $\mathrm{K}$ and $\mathrm{L}$ shared attending +organising +participating stakeholder engagements. Informant K described a 'main' current audience member role and a recent 'subsequent' role as an organising stakeholder. She had been employed by the Society, before leaving with the aim of pursuing an 'additional' freelance career as a promoter. Although she revealed heavily blurred roles, Informant $\mathrm{K}$ was clear on the three roles and their saliency:

"As a stakeholder I'm now an audience member, and I am [now] working for a venue, which is what I used to service, so... now l'll be promoting shows and or venues, and I'll be an audience member" (Informant K: attending +organising +participating stakeholder).

Informant L described himself as "difficult to pigeonhole as one particular stakeholder" and did not separate his roles easily. His 'main' role of attending the Fringe stemmed from childhood, visiting Edinburgh as an event tourist in the 1990s with his mother. He subsequently performed in a youth theatre company at the Fringe, before deciding to live in Edinburgh and attend University. Similarly to Informant N, he was influenced by his formative event tourism experiences of the Fringe. While studying, Informant $L$ worked in a number of venues and after graduating, the Society. Although no longer employed there, he remained an audience member. He emphasised his 'main' role as fore-mostly an attending stakeholder, but felt less engaged than before: "Now? I go and see shows. I mean I 'want' to be more a part of it than I have over the last couple of years, but l've got another job now". Informant $L$ spoke of being highly engaged in attending Fringe performances while he was 
an organising stakeholder, his professional position allowing more opportunities to attend, estimating: "the most l've ever seen in one August was forty-two shows". He reflected on his current 'main' role as an attending stakeholder in comparison with his historic engagement:

"Now I want to see as much as I can, but it tends to be in a fairly concentrated burst. If a friend comes to stay, I'll try and take a couple of days' holiday and maybe we'll go and see ten shows over the course of a weekend" (Informant L: attending +organising +participating stakeholder).

\subsubsection{Remaining informants' 'additional' stakeholder roles}

The remaining informants' 'additional' roles were defined in various ways. Informant F, a participating +attending organising stakeholder, had a 'main' role as a venue programmer; a 'subsequent' role as an attendee; and had previously worked for the Society in an 'additional' management role, describing: "working for the Fringe rather than contributing to it". In her 'main' role she revealed a higher level of salience in the Fringe, than she had while previously employed by the Society. Informant F described the atmosphere of the city and the "feeling as if you are participating in the festival" she had in her current roles. She also emphasised the hallmark characteristics of the Fringe being synonymous with, and embedded in, Edinburgh, stating: "if you don't have a sense of the place its taking place in then you almost don't have a sense of the festival".

Informant R, a supporting +attending +organising stakeholder was similarly emphatic in differentiating amongst his three roles. He assumed two professional and one personal involvement as an audience member. His 'main' role was working within a tourism organisation which supported the Fringe, with a current 'subsequent' attending role as an audience member. He had previously held an 'additional' organising role with the Society. Informant $\mathrm{R}$ discussed the hallmark event qualities of the symbolic and unique nature of the Fringe and its impact upon event tourism in Edinburgh, mentioning: "the spectacle... the transformation of the city [and] for me personally, I think there is the unique experience, because I'm there, and I'm going too!" Similarly, Informant J, being a participating +attending +organising stakeholder was a founding-member of a performing company in his 'main' role, and described himself across 'additional' participating stakeholder categories as he had worked for venues and the Society. He also emphasised his 'subsequent' role as an audience member demonstrating distinct blurring:

"I've had a number of different roles really. I worked as a performer last year and again this year and I'm also a producer. Almost all of our company have worked with the Fringe. I mean, I've worked as a front-of-house steward and l've always been an audience member!" (Informant $\mathrm{J}$, participating +attending +organising stakeholder) 
The final two informants with 'additional' roles shared 'main' engagements as current organising stakeholders and similar characteristics in terms of their complex relationships with the Fringe. Informant A (organising +attending +participating stakeholder) had twenty years' history with the Fringe. With a current 'main' role of organising stakeholder, being a staff member; and a 'subsequent' audience member role, she positioned herself within this category. However she was precise in her description of her previous roles, although demonstrated blurring between her 'main' and 'subsequent' roles:

"I'm quite clear on that! I'm first and foremost a member of Fringe Society staff! l've also been coming to the Fringe for eighteen years as an audience member. I've previously worked at venues, [and] I've worked on shows" (Informant A, organising +attending +participating stakeholder).

Informant $\mathrm{C}$ was the only stakeholder to describe concurrent 'main', 'subsequent' and 'additional' roles as an organising +participating +attending stakeholder. As a Society Member, he also managed and programmed venues and was an attendee. His stakeholder relationship was manifold with high levels of saliency in terms of reciprocal power, legitimacy and urgency (Mitchell et al., 1997). Informant C referred to his stakeholder engagement as fun and sociable while also requiring a need to be supportive on a professional basis. $\mathrm{He}$ described his stakeholder relationships in interpersonal terms as being "like a big dysfunctional family". Similarly to Informant A, Informant C was highly engaged and his relationship with the Fringe was complex and long-term as was the case for all of the stakeholders with 'main', 'subsequent' and 'additional' roles.

Insights into the engagement of hallmark event primary stakeholders are evident in these findings. In particular, the manifold nature of primary roles and within these the extreme extent of blurring and shifting that has occurred over time as stakeholders engage with hallmark event tourism is of significance. These findings make theoretical contributions to stakeholder theory in event tourism; have implications for stakeholder management in this setting; and are relevant to event portfolio development. The contributions of this study and future areas of research are now drawn together as conclusions.

\section{Conclusions}

The value attributed to stakeholder theory in the management literature is well-documented and the concept is widely applied in business and organisational practice. Given the critical role of primary stakeholders in tourism management and the limited attention that has been directed to understanding the engagement of these key groups, this paper has sought to address the lack of studies that explore the roles of stakeholders in specific tourism settings. Conclusions can therefore be drawn firstly in relation to this study's contribution to stakeholder theory; its methodological approach; and to management practice. Specific 
Todd, L., Leask, A. \& Ensor, J. (2016). Understanding primary stakeholders' multiple roles in hallmark event tourism management. Tourism Management. 59, pp.494-509. DOI: http://dx.doi.org/10.1016/j.tourman.2016.09.010

conclusions may be ascribed in terms of hallmark event tourism; destination management in practice; and in event and tourism studies.

\subsection{Theoretical contributions}

In its theoretical contributions, this paper adds new insights to stakeholder theory. This is in terms of uncovering the shifting and multiple roles of primary stakeholders, here determined as: 'main', 'subsequent' and 'additional'. Although the present study occured within a specific hallmark event tourism context, the findings presented are of relevance to gaining insights into the lived experiences of primary stakeholders as they engage with organisations. As noted, while some blurring of stakeholder roles was expected, the findings revealed that this was indeed the case for nineteen of the twenty-one informants. This contributes a new perspective to stakeholder theory in terms of providing evidence of various forms of primary stakeholder engagement over time in the setting of hallmark event tourism. This is relevant because the growing importance of event tourism in destination management is recognised and hallmark events are core components of destinations' managed event portfolios.

This study presents a new understanding of how stakeholders' primary roles are blurred and can change in this setting. It reveals the extreme extent to which primary roles are complex and indistinct. As discussed, the majority of stakeholders assume a series of varied 'main', 'subsequent' and 'additional' roles. Some are historic, and related to previous professional employment. Many operate concurrently, particularly in the case of present attending roles when combined with professional primary roles, for example those connected to the organising, support and production of the hallmark event. Conclusions may be drawn of relevance to other specific event tourism and destination management settings. The findings could also be explored in further organisational contexts within the service and experience industries.

The range of primary roles revealed in the present hallmark event tourism setting are characterised by five engagements of: organising, participating in, attending, supplying or supporting the event. The uncovering of these particular roles has implications to the greater understanding of existing hallmark events as a form of event; and the keystone position of these sought-after events within event tourism portfolio development, and destination management settings. For example, destination managers seeking to develop strategic event portfolios to drive event tourism could learn much from tracing the growth and development of existing hallmark events to gain an understanding their bespoke success factors of longevity and iconic status within the host destination. Many tourism destinations are already the symbiotic hosts of organically grown hallmark events and festivals. Valuable lessons learned from these settings could be applied to the conception, design and 
Todd, L., Leask, A. \& Ensor, J. (2016). Understanding primary stakeholders' multiple roles in hallmark event tourism management. Tourism Management. 59, pp.494-509. DOI: http://dx.doi.org/10.1016/j.tourman.2016.09.010

development of future-ready hallmark events; bringing with them the associated tangible and symbolic benefits to event tourism and destination development. Additionally, the findings of this study could make valuable contributions to the future design and management of hallmark events in terms of capturing and engaging primary stakeholders over the course of time as their roles change.

\subsection{Methodological contributions}

Another contribution is the present methodological approach of interviews with a phenomenological perspective in a specific stakeholder setting to gain an understanding of informants' lived experience of phenomena. The study first developed a generic stakeholder typology to the setting of a hallmark event within an event tourism context, specifically that of the Fringe in Edinburgh. This was underpinned by existing stakeholder and tourism management literature and applied document analysis and key informant consultation to inform the specific setting under investigation. Through the use of stakeholder interviews with a phenomenological perspective, to gain an understanding of the lived experiences of primary stakeholders, this study uncovered new knowledge of the roles and engagement of these informants in this particular setting, and explored how these had changed over time. The use of such phenomenological interviews was valuable in the elicitation of rich details of informants' lived experiences and memories of their various engagements with the Fringe as they had experienced it. As an approach, the present method could have future potential in similar research seeking to understand stakeholders' lived experience and life-worlds; and specifically how they engage with tourism destinations, organisations and other phenomena.

\subsection{Management implications}

Although limited to the present empirical setting, this study has implications for managers involved in strategic event portfolio management. These include a new understanding of the ways in which essential primary stakeholders engage with hallmark events over time and how their salience and roles shift. This is relevant to destination managers seeking to establish future hallmark events as well as sustain successful hallmark events within their managed event portfolios. Being at the core of event tourism management, hallmark events and their various stakeholders may indeed be regarded as the foundations of managed event portfolios and tourism management in this setting. Based on the multiple nature of stakeholders' roles uncovered, this study has management implications when considered in relation to stakeholder saliency in hallmark event tourism and tourism management. In this case, those stakeholders with one 'main' primary role were attendees of the Fringe and this particular engagement was predictably positive, being voluntary. However, the relative saliency upon the Fringe, in terms of the power, urgency and legitimacy of stakeholders with 
a single 'main' primary role of this type is likely to be less pronounced than those with a 'main' stakeholder role engaged in a professional capacity and a subsequent attending role. This is particularly in the case of those stakeholders assuming a 'main', 'subsequent', and an 'additional' primary role. As this study revealed, in the present setting all of these informants currently or previously had organising stakeholder roles, working with the Society in various capacities. Some had also assumed further roles as participants, including venue managers and performers. In terms of these individuals' relationships with the event, they were also the most engaged with the Fringe as a hallmark event.

\subsection{Limitations}

Despite the potential of this study's findings, a limitation is the research is specific to the event tourism situation of the Edinburgh Festival Fringe. As a hallmark event which has developed in an almost entirely organic manner over seventy years, the setting of the present study is unique. Indeed, as a phenomenon, the Fringe itself is not replicable. This is important and significant to note. Unlike other hallmark events, the Fringe does not have a clearly defined stakeholder map of inter-relationships. Neither the salience levels nor power of individual stakeholders in the overall management of the festival may be defined. As noted earlier, not one individual or group of stakeholders is responsible for strategic decision-making within the Fringe due to its organic and open-access design. Rather, it occurs due to the interaction of its five groups of primary stakeholders within Edinburgh's event tourism setting. Although unlikely to operate as the Fringe does, it is important to recognise that tourism contexts and destination management approaches differ across countries and regions; and throughout the various component parts of tourism's industry and economic sectors that are likely to face their own unique circumstances requiring them to manage and relate to stakeholders in different ways.

\subsection{Future research}

Despite its limitations, this study does have important implications for tourism managers and policy makers. In terms of the present findings and emerging recognition of the importance of hallmark events and event tourism; the significance of the present findings should be noted. New research questions emerge with a number of potential future areas worthy of investigation. Future studies could study further individual existing hallmark events and primary stakeholders' lived experiences, to understand how destination managers can build relationships with current and future stakeholders of hallmark event tourism, and how engagements change over time. This could provide insights into patterns of changing stakeholders' roles as they are extended and blurred, or stakeholders' lifecycles in their 
engagement with hallmark events over time providing a future perspective on event tourism development and portfolio management.

Further, the conclusions and the implications of these to further tourism management contexts is relevant. Although the present study's focus is event tourism, and specifically hallmark events, the research approach to unpacking the multiple roles of primary stakeholders could be applied and extended in specific contexts. Stakeholder roles and engagement could be considered in individual tourism contexts such as visitor attractions, cultural and heritage sites, hotels or resorts; as well as within managed tourism destinations, such as cities or natural areas, in terms of portfolio development and experience design. Opportunities for tourism managers and policy makers to understand the engagement and roles of primary stakeholders in these tourism settings could be significant in better understanding stakeholders' saliency and how this is affected by changing roles and relationships. It is hoped that this study establishes a channel for other researchers to advance further the findings uncovered and issues discussed here.

Decision-making, power and inter-relationships of primary stakeholders in the setting of the Fringe have not been addressed by this study; which was concerned with primary stakeholders' roles and how these are characterised. As discussed, the Fringe has an openaccess management design which does not lend itself to one stakeholder taking strategic control. Nevertheless, due to its complexity and the changing roles and impact of groups such as contributing stakeholders; it would be interesting to undertake a study into the interests, conflicts and power of primary stakeholders in this organic setting. For example, recent media attention has focused on the inexorable growth of the Fringe and its ensuing commercialisation through the involvement of large venue-managing conglomerates and corporate sponsors and gaining a deeper understanding of the roles of these stakeholders could provide insights into the future management of the Fringe and other hallmark events. A useful template to undertake such a study could be the Political Market Square (PSQ) event network metaphor (Larson, 2002) which presents three metaphorical PSQs of a tumultuous 'jungle'; dynamic 'park'; and institutionalised 'garden'. While the literature recognises hallmark events as being institutionalised, it would be interesting to uncover the extent to which this is the case for the Fringe in terms of stakeholders' perceptions of its power relationship networks. Such a study could be of value to further hallmark event tourism managers.

Notably while the present study is concerned with understanding the roles of primary stakeholders specifically, the various engagements of the actors within the contextual secondary stakeholders' network remains unexplored. Undertaking a similar investigation of 
the roles of secondary stakeholders, including overlaps and relationships with primary roles, could facilitate a greater in-depth understanding of stakeholder networks in selected tourism contexts. Of significance to tourism management and as previously mentioned, the present study found those stakeholders with the largest number of primary roles, and who were the most positively engaged with the Fringe, had all previously been, or were currently, organising stakeholders. They had themselves been at some time involved in managing the Fringe in some way. In further tourism contexts, such as those mentioned above, this category could include managers, workers and volunteers in one or more organisations such as destinations and visitor attractions. Future research could address the significance of these particular stakeholders in terms of gaining an understanding of their salience within specific tourism contexts and organisations. From a management perspective, research could investigate how destination and tourism managers can ensure they are in a position to encourage and facilitate positive, lifelong and multi-faceted relationships with their employees, during and beyond this important form of primary engagement.

To conclude, this paper has contributed new insights into stakeholder theory in event tourism management; and as discussed, these are applicable in further tourism and destination areas, both conceptually and in management terms. The methodological approach to the development of the primary and secondary stakeholder typology contributes to stakeholder theory as it applies existing theoretical frameworks to an empirical setting. Finally, the application of phenomenologically inspired interviews has been revealing in providing rich and valuable insights into the lived experiences, shifting roles, and engagements, of stakeholders in the setting of hallmark event tourism. 


\section{References}

Aas, C., Ladkin, A., \& Fletcher, J. (2005). Stakeholder collaboration and heritage management. Annals of Tourism Research, 32(1), 28-48.

Ackoff, R. (1981). Creating the corporate future: Plan or be planned for. New York: Wiley.

Andereck, K. \& Vogt, C. (2000). The relationship between residents' attitudes toward tourism and tourism development options. Journal of Travel Research, 39(1)

Andersson, T. \& Getz, D. (2008). Stakeholder management strategies of festivals. Journal of Convention \& Event Tourism (Vol. 9, No. 3, pp. 199-220). Taylor \& Francis Group.

Benur, A. \& Bramwell, B. (2015). Tourism product development and product diversification in destinations. Tourism Management, 50, 213-224.

Beritelli, P. \& Laesser, C. (2011). Power dimensions and influence reputation in tourist destinations: Empirical evidence from a network of actors and stakeholders. Tourism Management, 32(6), 1299-1309.

Berger, P. \& Luckmann, T. (1991). The social construction of reality: A treatise in the sociology of knowledge (No. 10). Penguin UK.

BOP Consulting \& Festivals and Events International. (2015) Thundering Hooves 2.0. Retrieved 29th May 2015, from: http://www.edinburghfestivalcity.com/assets/000/000/823/TH_2_0_full_report_original.pdf?1432048731

Bornhorst, T., Ritchie, J. B., \& Sheehan, L. (2010). Determinants of tourism success for DMOs \& destinations: An empirical examination of stakeholders' perspectives. Tourism Management, 31(5), 572-589.

Bowdin, G., Allen, J., O'Toole, W., Harris, R., \& McDonnell, I. (2011). Events Management. Oxford: Elsevier Butterworth-Heinemann.

Caffyn, A., \& Jobbins, G. (2003). Governance capacity and stakeholder interactions in the development and management of coastal tourism: examples from Morocco and Tunisia. Journal of Sustainable Tourism, 11(2-3), 224-245

Campbell, A. (1997). Stakeholders: the case in favour. Long Range Planning, 30, 446-449.

Carroll, A. B. (1991). The pyramid of corporate social responsibility: Toward the moral management of organizational stakeholders. Business Horizons, 34(4), 39-48.

Carson, D., Gilmore, A., Perry, C., \& Gronhaug, K. (2001). Qualitative marketing research. Sage.

Clarkson, M. (1995). A stakeholder framework for analyzing and evaluating corporate social performance. Academy of Management Review, 20, 92-117.

Connell, J., Page, S., \& Meyer, D. (2015). Visitor attractions and events: Responding to seasonality. Tourism Management, 46, 283-298.

Coughlan, D., \& Mules, T. (2001). Sponsorship awareness and recognition at Canberra's Floriade festival. Event Management, 7, 1-9.

Crotty, M. (1998). The foundations of social research: Meaning and perspective in the research process. Sage. 
Creswell, J. (2013). Research design: Qualitative, quantitative, and mixed methods approaches. Sage.

Delamere, T. (2001). Development of a scale to measure resident attitudes toward the social impacts of community festivals, Part II: Verification of the scale. Event Management, 7, 25-38.

Delamere, T., Wankel, L., \& Hinch, T. (2001). Development of a scale to measure resident attitudes towards the social impacts of community Festivals, Part I: Item generation and purification of the measure. Event Management, 7, 11-24.

Delanty, G. (1997). Social science: Beyond constructivism and realism. U of Minnesota Press.

Denzin, N., \& Lincoln Y. (Eds.). (2011). The Sage handbook of qualitative research. Sage (4 ${ }^{\text {th }}$ Edition)

Donaldson, T., \& Preston, L. (1995). The Stakeholder Theory of the Corporation: Concepts, Evidence, and Implications. The Academy of Management Review, 20, 65-91.

Edinburgh Festival City (2016) About Edinburgh Festival City. Retrieved $15^{\text {th }}$ January 2015 from: http://www.edinburghfestivalcity.com/about

Edinburgh Festival Fringe Society, (2015) What the Fringe?! After 50,459 performances of 3,314 shows, the 2015 Edinburgh Festival Fringe draws to a close. Retrieved 10 ${ }^{\text {th }}$ September 2015, from: https://www.edfringe.com/media/news/what-the-fringe-after-50459-performances-of-3-314-shows-the-2015-edinburgh-festival-fringe-draws-to-a-close

Edinburgh Festival Fringe Society, (2016) About the Edinburgh Festival Fringe. Retrieved $14^{\text {th }}$ January 2016, from: https://www.edfringe.com/aboutus?gclid=CLn2u9SNIsMCFUvJtAodrAEAUA

Fassin, Y. (2009). The stakeholder model refined. Journal of business ethics, 84(1), 113135.

Festivals Edinburgh \& BOP Consulting, (2011) Edinburgh Festivals Impact Study [Online]. Retrieved $30^{\text {th }}$ July 2015 , from:

http://www.festivalsedinburgh.com/sites/default/files/Edinburgh\%20festivals\%202010\% 20Impact\%20Study\%20Report.pdf

Fournier, S. (1998). Consumers and their brands: Developing relationship theory in consumer research. Journal of Consumer Research, 24, 343-353.

Fredline, E. (2000). Host community reactions to major sporting events: The Gold Coast Indy and the Australian Formula One Grand Prix in Melbourne (Doctoral dissertation, Griffith University, Australia). Retrieved from: http://www4.gu.edu.au:8080/adtroot/public/adt-QGU20030226.083759/.

Freeman, R. (1984). Strategic management: A stakeholder approach. Boston: Pitman.

Freeman, R. (1994). The politics of stakeholder theory: Some future directions. Business ethics quarterly, 409-421.

Freeman, R. (2010). Strategic management: A stakeholder approach. Cambridge University Press 
Freeman, R. \& Reed, D. (1983). Stockholders and stakeholders: A new perspective in corporate governance. California management review, 25, 88-106.

Frooman, J. (1999). Stakeholder influence strategies. Academy of management review, 24(2), 191-205.

Frost, W. (2012), Events and tourism, in Page, S., and Connell, J. (Eds), Routledge Handbook of Events, Routledge, London, pp. 75-86.

García, J. Gómez, M., \& Molina, A. (2012). A destination-branding model: An empirical analysis based on stakeholders. Tourism Management, 33(3), 646-661.

Garrod, B., Fyall, A., Leask, A., \& Reid, E. (2012). Engaging residents as stakeholders of the visitor attraction. Tourism Management, 33(5), 1159-1173.

Getz, D. (1991). Festivals, special events, and tourism. Van Nostrand Reinhold.

Getz, D. (1993). Case study: Marketing the Calgary exhibition and stampede. Festival Management and Event Tourism, 1(4), 147-156.

Getz, D. (2002). Event studies and event management: On becoming an academic discipline. Journal of Hospitality and Tourism Management, 9(1), 12-23.

Getz, D. (2008). Event tourism: Definition, evolution, and research. Tourism Management, 29(3),403-428.

Getz, D. (2012a). Event studies: Theory, research and policy for planned events (2 ${ }^{\text {nd }}$ ed.): Elsevier Butterworth-Heinemann.

Getz, D. (2012b). Event Studies. In S. Page, \& J. Connell (Eds.), Routledge Handbook of Events. London: Routledge.

Getz, D., \& Andersson, T. (2008). Sustainable festivals: On becoming an institution. Event Management, 12(1),1-17.

Getz, D., \& Andersson, T. (2010). Festival stakeholders: Exploring relationships and dependency through a four-country comparison. Journal of Hospitality \& Tourism Research.

Getz, D., Andersson, T., \& Larson, M. (2006). Festival stakeholder roles: Concepts and case studies. Event Management, 10(2-3),103-122.

Getz, D., \& Jamal, T. B. (1994). The environment-community symbiosis: A case for collaborative tourism planning. Journal of Sustainable Tourism, 2(3), 152-173.

Getz, D., \& Page, S. J. (2016). Progress and prospects for event tourism research. Tourism Management, 52, 593-631.

Getz, D., Svensson, B., Peterssen, R., \& Gunnervall, A. (2012). Hallmark events: Definition, goals and planning process. International Journal of Event Management Research, 7(1/2), 47-67.

Gibson, C. \& Davidson, D. (2004) Tamworth, Australia's 'country music capital': Place marketing, rurality, and resident reactions. Journal of Rural Studies 20: 387-404

Gilmore, F. (2002). A country-Can it be repositioned? Spain- The success story of country branding. The Journal of Brand Management, 9(4), 281-293.

Goodman, L. A. (1961). Snowball sampling. The Annals of Mathematical Statistics, 148-170. 
Graham, S., Goldblatt, J. J., \& Delpy Neirotti, L. (1995). The ultimate guide to sport event management and marketing. Irwin Professional.

Gwinner, K. (1997). A model of image creation and image transfer in event sponsorship. International Marketing Review, 14, 145-158.

Hall, C. M. (1989). The definition and analysis of hallmark tourist events. GeoJournal, 19(3), 263-268.

Hall, C. M. (1992). Hallmark tourist events: impacts, management and planning. Belhaven Press.

Hankinson, G. (2004). Relational network brands: Towards a conceptual model of place brands. Journal of Vacation Marketing, 10(2), 109-121.

Harrison, J. S., \& Freeman, R. E. (1999). Stakeholders, social responsibility, and performance: Empirical evidence and theoretical perspectives. Academy of Management Journal, 42(5), 479-485.

Hede, A. M. (2007). Managing special events in the new era of the triple bottom line. Event Management, 11(1-2), 13-22.

Heenan, D. (1978). Tourism and the community a drama in three acts. Journal of Travel Research, 16(4), 30-32.

Hiller, H. (2000). Mega-events, urban boosterism and growth strategies: an analysis of the objectives and legitimations of the Cape Town 2004 Olympic Bid. International Journal of Urban and Regional Research, 24(2), 449-458.

Holt, D. (2004). How brands become icons: The principles of cultural branding. Harvard Business Press.

Imran, S., Alam, K., \& Beaumont, N. (2014). Environmental orientations and environmental behaviour: Perceptions of protected area tourism stakeholders. Tourism Management, 40, 290-299.

Ind, N. \& Todd, L. (2011) 'Beyond the Fringe: creativity and the city' in F. Go and R. Govers (eds.) International Place Branding Yearbook 2011: reputation under pressure, Chippenham: Palgrave Macmillan, pp.47-59.

Jamal, T., \& Getz, D. (1995). Collaboration theory and community tourism planning. Annals of Tourism Research, 22(1), 186-204.

Jawahar, I., \& McLaughlin, G. (2001). Toward a descriptive stakeholder theory: An organizational life cycle approach. Academy of Management Review, 26, 397-414.

Johnson, G., Scholes, K., \& Whittington, R. (2008). Exploring corporate strategy (8th ed.): FT Prentice Hall.

Kim, W., Jun, H. M., Walker, M., \& Drane, D. (2015). Evaluating the perceived social impacts of hosting large-scale sport tourism events: Scale development and validation. Tourism Management, 48, 21-32.

Kvale, S. (1996). Interviews: An introduction to qualitative research interviewing. Thousand Oaks, CA: Sage.

Kvale, S., \& Brinkmann, S. (2009). Interviews: Learning the craft of qualitative research interviewing. Sage. 
Larson, M. (2002). A political approach to relationship marketing: Case study of the Storsjöyran festival. International Journal of Tourism Research, 4, 119-143.

Larson, M. (2009). Joint event production in the jungle, the park, and the garden: Metaphors of event networks. Tourism Management, 30(3), 393-399.

Larson, M., Wikstrom, E. (2001). Organizing events: managing conflict and consensus in a political market square. Event Management, 7, 51-65.

Lincoln, Y., Lynham, S., \& Guba, E. (2011). Paradigmatic controversies, contradictions, and emerging confluences, revisited. The Sage handbook of qualitative research, 4, 97128.

Magness, V. (2008). Who are the stakeholders now? An empirical examination of the Mitchell, Agle, and Wood theory of stakeholder salience. Journal of Business Ethics, 83(2), 177-192.

Marshall, M. (1996a). Sampling for qualitative research. Family Practice, 13(6), 522-526.

Marshall, M. (1996b). The key informant technique. Family Practice, 13(1), 92-97.

McKercher, B. (2016). Towards a taxonomy of tourism products. Tourism Management, 54, 196-208.

McVea, J., \& Freeman, R. (2005). A Names-and-faces approach to stakeholder management how focusing on stakeholders as individuals can bring ethics and entrepreneurial strategy together. Journal of Management Inquiry, 14(1), 57-69.

Merrilees, B., Getz, D., \& O'Brien, D. (2005). Marketing stakeholder analysis: Branding the Brisbane Goodwill Games. European Journal of Marketing, 39, 1060-1077.

Mitchell, R., Agle, B., \& Wood, D. (1997). Toward a theory of stakeholder identification and salience: defining the principle of who and what really counts The Academy of Management Review, 22, 853-886.

Moffat, A. (1978). The Edinburgh Fringe. Johnston \& Bacon.

Morse, J. (1995). The significance of saturation. Qualitative Health Research, 5(2), 147-149.

Mossberg, L., \& Getz, D. (2006). Stakeholder influences on the ownership and management of festival brands. Scandinavian Journal of Hospitality and Tourism, 308 - 326.

Page, S., \& Connell, J. (2009). Event Tourism: Critical concepts in tourism. Routledge

Palmer, A., \& Bejou, D. (1995). Tourism destination marketing alliances. Annals of Tourism Research, 22(3), 616-629.

Patterson, I., \& Getz, D. (2013). At the nexus of leisure and event studies. Event Management, 17(3), 227-240.

Pernecky, T., \& Jamal, T. (2010). (Hermeneutic) Phenomenology in tourism studies. Annals of Tourism Research, 37(4), 1055-1075.

Pernecky, T. (2012). Constructionism: Critical pointers for tourism studies. Annals of Tourism Research, 39(2), 1116-1137.

Pike, S. (2009). Destination brand positions of a competitive set of near-home destinations. Tourism Management, 30(6), 857-866. 
Pine, J. and Gilmore, J. (1998) Welcome to the experience economy, Harvard Business Review, 76: 97-105.

Quinn, B. (2005). Arts festivals and the city. Urban Studies, 42, 927-943.

Randle, E., \& Hoye, R. (2016). Stakeholder perception of regulating commercial tourism in Victorian National Parks, Australia. Tourism Management, 54, 138-149.

Reid, S. (2011). Event stakeholder management: developing sustainable rural event practices. International Journal of Event and Festival Management, 2(1), 20-36.

Reid, S. (2006). Identifying social consequences of rural events. Event Management, 11(12), 89-98.

Reid, S., \& Arcodia, C. (2002, 15th-16th July, 2002). Understanding the role of the stakeholder in event management. Paper presented at: Events and place making. UTS Business: Event research conference, UTS Australian Centre for Event Management, University of Technology, in association with CRC in Sustainable Tourism Sydney, Australia.

Richards, G., \& Palmer, R. (2012). Eventful cities. Routledge.

Ritchie, J. B. (1984). Assessing the impact of hallmark events: conceptual and research issues. Journal of Travel Research, 23(1), 2-11.

Ritchie, J. B., \& Beliveau, D. (1974). Hallmark events: An evaluation of a strategic response to seasonality in the travel market. Journal of Travel Research, 13(2), 14-20.

Ritchie, J. B., \& Crouch, G. (2003). The competitive destination: A sustainable tourism perspective. Cabi.

Robson, J., \& Robson, I. (1996). From shareholders to stakeholders: critical issues for tourism marketers. Tourism Management, 17(7), 533-540.

Roth, W., \& Breuer, F. (2003, May). Reflexivity and subjectivity: A possible road map for reading the special issues. In: Forum Qualitative Sozialforschung/Forum: Qualitative Social Research (Vol. 4, No. 2).

Rowley, T. (1997). Moving beyond dyadic ties: A network theory of stakeholder influences. Academy of Management Review, 22(4), 887-910.

Sautter, E., \& Leisen, B. (1999). Managing stakeholders a tourism planning model. Annals of Tourism Research, 26(2), 312-328.

Savage, G., Nix, T., Whitehead, C., \& Blair, J. (1991). Strategies for assessing and managing organizational stakeholders. The Executive, 5(2), 61-75.

Scott, S., \& Lane, V. (2000). A stakeholder approach to organizational identity. Academy of Management Review, 25(1), 43-62.

Smith, C., \& Jenner, P. (1998). The impact of festivals and special events on tourism. Travel \& Tourism Analyst, (4), 73-91.

Spiropoulos, S., Gargalianos, D., \& Sotiriadou, K. (2006). The 20th Greek Festival of Sydney: A stakeholder analysis. Event Management, 9, 169-183.

Stokes, R. (2008). Tourism strategy making: Insights to the events tourism domain. Tourism Management, 29(2), 252-262. 
Strong, K., Ringer, R., \& Taylor, S. (2001). THE* Rules of stakeholder satisfaction ( ${ }^{*}$ Timeliness, Honesty, Empathy). Journal of Business Ethics, 32, 219-230.

Suchman, M. (1995). Managing legitimacy: Strategic and institutional approaches. Academy of management review, 20(3), 571-610.

Timothy, D., (1999). Participatory planning: a View of Tourism in Indonesia. Annals of Tourism Research, 26(2), 371-391.

Thompson, C., Locander, W., \& Pollio, H. (1989). Putting consumer experience back into consumer research: the philosophy and method of existential-phenomenology. Journal of Consumer Research, 133-146.

Todd, L. (2014). Developing brand relationship theory for festivals: a study of the Edinburgh Festival Fringe, In: I. Yeoman, M. Robertson, U. McMahon-Beattie, E. Backer \& K, Smith (Eds) The Future of Events and Festivals, Routledge Advances in Event Research Series.

Van Aalst, I., \& van Melik, R. (2012). City festivals and urban development: does place matter? European Urban and Regional Studies, 19(2), 195-206.

Waligo, V., Clarke, J., \& Hawkins, R. (2013). Implementing sustainable tourism: A multistakeholder involvement management framework. Tourism Management, 36, 342-353.

Wood, D., \& Gray, B. (1991). Toward a comprehensive theory of collaboration. The Journal of Applied Behavioral Science, 27(2), 139-162.

World Fringe Network (2016) Home, Retrieved $4^{\text {th }}$ January 2016, from: http://www.worldfringe.com/

Wray, M. (2011). Adopting and implementing a transactive approach to sustainable tourism planning: Translating theory into practice. Journal of Sustainable Tourism, 19(4-5), 605-627.

Xue, H., \& Mason, D.S. (2011). The changing stakeholder map of Formula One Grand Prix in Shanghai. European Sport Management Quarterly, 11(4), 371-395.

Yasarata, M., Altinay, L., Burns, P., \& Okumus, F. (2010). Politics and sustainable tourism development-Can they co-exist? Voices from North Cyprus. Tourism Management, 31(3), 345-356.

Ziakas, V. (2015). For the benefit of all? Developing a critical perspective in mega-event leverage. Leisure Studies, 34(6), 689-702.

Ziakas, V., \& Boukas, N. (2014). Contextualizing phenomenology in event management research: Deciphering the meaning of event experiences. International Journal of Event and Festival Management, 5(1), 56-73. 